\title{
Internal Controls For Public Sector Entities
}

\author{
Jeffrey L. Decker, Ph.D., CPA, Indiana State University, USA
}

\begin{abstract}
In a manner consistent with Heinze et al (2010), this paper focuses on revenue-related internal controls in the public sector. This paper can be used to benchmark whether public sector entities have proper internal controls in place. Finally, this paper can be used in the classroom to demonstrate how public sector entity internal controls need to be designed.
\end{abstract}

Keywords: Internal Control; Control Objectives; Control Procedures; Public Sector

\section{OVERVIEW}

How Money defines a public sector entity as:

a presence of government in the form of a business activity. These activities can take organizational form in three areas; tax design, where the public sector presence has no incentive to be profitable since costs are borne by taxpayers, corporate model where the public-owned corporations must conform to the same rules as private businesses, and outsourcing, where the government contracts out the service and is a government function in name only.

Public sector entities continue to be a major component of most developed countries economic systems, including the United States. Brunsson and Sahlin-Andersson (2000) found that public sector entities were transforming into more complete organizations by reinforcing hierarchy and rationality, both of which would be part of any competent system of internal control.

Recognizing the transformation of public sector entities into more formal organizations, the United States General Accounting Office in 1999 released a revised version of "Standards of Internal Control for the Federal Government", which provides guidance not only to federal organizations, but state and local ones as well. Among the areas covered include:

The Federal Managers' Financial Integrity Act of 1982 (FMFIA) requires the General Accounting Office (GAO) to issue standards for internal control in government. The standards provide the overall framework for establishing and maintaining internal control and for identifying and addressing major performance and management challenges and areas at greatest risk of fraud, waste, abuse, and mismanagement. Also, the Chief Financial Officers Act of 1990 calls for financial management systems to comply with internal control standards, and the Federal Financial Management Improvement Act of 1996 identifies internal control as an integral part of improving financial management systems.

Internal Control

An integral component of an organization's management that provides reasonable assurance that the following objectives are being achieved:

- $\quad$ effectiveness and efficiency of operations,

- $\quad$ reliability of financial reporting, and

- $\quad$ compliance with applicable laws and regulations. 
Monitoring of internal control should include policies and procedures for ensuring that the findings of audits and other reviews are promptly resolved. Managers are to (1) promptly evaluate findings from audits and other reviews, including those showing deficiencies and recommendations reported by auditors and others who evaluate agencies' operations, (2) determine proper actions in response to findings and recommendations from audits and reviews, and (3) complete, within established time frames, all actions that correct or otherwise resolve the matters brought to management's attention. The resolution process begins when audit or other review results are reported to management, and is completed only after action has been taken that (1) corrects identified deficiencies, (2) produces improvements, or (3) demonstrates the findings and recommendations do not warrant management action.

The Federal government is clearly interested in the internal control systems in place at public sector firms and believes that part of any good internal control system is the minimization of waste and fraud. It is also clear that a formal independent audit procedure is a necessary part of the process. The revenue cycle continues to be the primary area of waste and fraud requiring appropriate internal controls (Heinze et al, 2010). Similar to Heinze et al (2010), this paper focuses on the high risk area of revenues. This paper provides a control review checklist for the revenue cycle of public sector entities. It can be an aid to developing internal controls as well as an aid in auditing them.

\section{A REVENUE CYCLE REVIEW CHECKLIST FOR PUBLIC SECTOR ENTITIES}

Using the identical layout presented in Heinze et al (2010), Tables 1 and 2 present a checklist of control objectives and activities that should be referenced when conducting a preliminary audit of public sector revenue. Table 1 lists significant revenue cycle control objectives. The objectives are followed by alpha numeric characters that reference the control activities listed in Table 2. The numeric portion of the reference explicitly refers to the control activities (listed numerically in Table 2), and the alpha portion ("F" or "P") indicates whether or not the referenced activity "fully" or "partially" meets the given objective's requirements.

Table 1 - Control Objectives and Suggested Control Activities

\begin{tabular}{|c|c|}
\hline Control Objectives & $\begin{array}{l}\text { Control Activities } \\
\text { Listed in Table } 2\end{array}$ \\
\hline All programs and services are approved by management. & $1 \mathrm{~F}, 4 \mathrm{~F}$ \\
\hline Program rates, fees and fines are approved by management. & $2 \mathrm{~F}$ \\
\hline Citizen information, and rates, fees and fines are input accurately. & $3 \mathrm{P}, 4 \mathrm{~F}, 5 \mathrm{~F}$ \\
\hline $\begin{array}{l}\text { All programs and services are entered in or transferred to the system which generates invoices } \\
\text { and records revenues. }\end{array}$ & $3 \mathrm{P}, 4 \mathrm{~F}, 6 \mathrm{~F}, 7 \mathrm{P}, 8 \mathrm{P}$ \\
\hline Invoices are generated using authorized terms, rates and fees. & $5 \mathrm{~F}, 9 \mathrm{~F}, 10 \mathrm{P}$ \\
\hline Invoices are accurately calculated and recorded. & $3 \mathrm{P}, 5 \mathrm{~F}, 10 \mathrm{P}, 11 \mathrm{~F}, 12 \mathrm{~F}$ \\
\hline Refunds and other adjustments to accounts receivable are accurately calculated and recorded. & $3 \mathrm{P}, 13 \mathrm{~F}, 14 \mathrm{P}, 15 \mathrm{P}$ \\
\hline All entities/individuals utilizing services are invoiced. & $4 \mathrm{~F}, 16 \mathrm{~F}, 17 \mathrm{P}$ \\
\hline All invoices issued are recorded. & $3 \mathrm{P}, 4 \mathrm{~F}, 16 \mathrm{~F}, 17 \mathrm{P}$ \\
\hline All refunds issued are recorded. & $3 \mathrm{P}, 4 \mathrm{P}, 18 \mathrm{~F}$ \\
\hline All refunds relate to valid adjustments. & $18 \mathrm{~F}, 19 \mathrm{~F}$ \\
\hline Invoices relate to valid programs and services. & $4 \mathrm{~F}, 10 \mathrm{P}, 16 \mathrm{~F}, 17 \mathrm{P}$ \\
\hline Invoices are recorded in the correct period. & $3 \mathrm{P}, 4 \mathrm{~F}, 16 \mathrm{~F}, 20 \mathrm{P}$ \\
\hline Refunds are recorded in the correct period. & $4 \mathrm{P}, 17 \mathrm{~F}, 20 \mathrm{~F}$ \\
\hline $\begin{array}{l}\text { Accounts receivable reflect the existing business circumstances and economic conditions in } \\
\text { accordance with the accounting polices being used. }\end{array}$ & $23 \mathrm{~F}$ \\
\hline \multicolumn{2}{|l|}{$\begin{array}{l}\text { Revenue from programs and other services and related receivable information is appropriately } \\
\text { presented and all information that is necessary for fair presentation and compliance is disclosed. }\end{array}$} \\
\hline Cash receipts are recorded in the period in which they are received. & 21F, 22F, 24P, 37P, 42F \\
\hline Cash receipts data is entered for processing accurately. & 10P, 21F, 24P, 25F, 26F, 37P, 39P, 41P \\
\hline All cash receipts data is entered for processing. & $10 \mathrm{P}, 21 \mathrm{~F}, 24 \mathrm{P}, 25 \mathrm{~F}, 37 \mathrm{P}, 38 \mathrm{P}$ \\
\hline Cash receipts data is valid and is entered for processing only once. & $21 \mathrm{~F}, 24 \mathrm{P}, 25 \mathrm{~F}, 37 \mathrm{P}, 39 \mathrm{P}, 40 \mathrm{P}, 43 \mathrm{P}$ \\
\hline Timely collection of accounts receivable is monitored. & $27 \mathrm{~F}, 36 \mathrm{~F}$ \\
\hline Only valid changes are made to the billing master files. & 28P, 29F, 30P, 31P, 32F \\
\hline All valid changes to the billing master files are input and processed. & $28 \mathrm{P}, 33 \mathrm{~F}, 34 \mathrm{~F}$ \\
\hline Changes to the billing master files are accurate. & $28 \mathrm{P}, 29 \mathrm{~F}, 35 \mathrm{~F}$ \\
\hline Changes to the billing master files are processed timely. & $28 \mathrm{P}, 33 \mathrm{~F}, 34 \mathrm{~F}$ \\
\hline Billing master files data remains pertinent. & $28 \mathrm{P}, 31 \mathrm{P}$ \\
\hline
\end{tabular}


Table 2 - Suggested Control Activities

\begin{tabular}{|c|c|}
\hline 1 & pparison of programs and services offered to authorized listing of programs and services. \\
\hline 2 & $\begin{array}{l}\text { Services provided and organization activities have an approved billing rate table. Exceptions to standard rates require specific } \\
\text { management approval. }\end{array}$ \\
\hline 3 & Review of recorded revenues and comparison to budgeted revenues on a regular basis. \\
\hline 4 & Analyze recorded revenues based on service and activity department data. \\
\hline 5 & $\begin{array}{l}\text { Invoices are checked against citizen data, verification of proper billing rates used on invoice, mathematical accuracy of invoices is } \\
\text { checked. }\end{array}$ \\
\hline 6 & $\begin{array}{l}\text { Revenues and/or related accounts receivable subsidiary ledgers are reconciled to the general ledger on a regular basis; identified errors } \\
\text { are corrected promptly. }\end{array}$ \\
\hline 7 & Recorded invoices/assessments and refunds are mailed to citizens. \\
\hline 8 & Past due invoices/assessments are investigated \\
\hline 9 & Invoices are based on an approved billing rate table. Exceptions to standard rates require specific management approval. \\
\hline 10 & Statements of accounts receivable are mailed to citizens. \\
\hline 11 & Invoices are automatically priced by the application system, using standard rates. \\
\hline 12 & Accuracy of recorded invoices is independently recalculated. \\
\hline 13 & Management approves refunds, bad-debt write-offs, and other adjustments to accounts receivable. \\
\hline 14 & Management monitors the nature, volume and amounts of recorded write-offs and other adjustments to accounts receivable. \\
\hline 15 & Invoices are edited and validated: identified errors are corrected promptly. \\
\hline 16 & Management compares invoices and revenue reports to service and activity department data. \\
\hline 17 & Invoices, contracts and activity tickets are sequentially prenumbered and accounted for. \\
\hline 18 & $\begin{array}{l}\text { Management compares refunds, write offs and other adjustments to refund vouchers, credit memos and other revenue adjustment } \\
\text { records. }\end{array}$ \\
\hline 19 & A policy has been established regarding criteria for issuing refunds; compliance with this policy is monitored. \\
\hline 20 & $\begin{array}{l}\text { A policy has been established regarding criteria for recording revenue and corresponding adjustments for programs and services which } \\
\text { overlap two fiscal periods. }\end{array}$ \\
\hline 21 & $\begin{array}{l}\text { Cash receipts are recorded using cash registers. Customers are provided with a copy of the register receipt and total daily receipts per } \\
\text { the register are balanced to cash deposited to the bank. }\end{array}$ \\
\hline 22 & $\begin{array}{l}\text { Cash receipts at, before, and after the end of an accounting period are scrutinized and/or reconciled to ensure complete and consistent } \\
\text { recording in the appropriate accounting period. }\end{array}$ \\
\hline 23 & Management reviews and approves the allowance for doubtful debts. \\
\hline 24 & Bank Statements are reconciled to the general ledger on a regular basis. \\
\hline 25 & Cash receipts transactions are batched and batch input data is balanced; out of balance batches are corrected promptly. \\
\hline 26 & Cash receipts data is edited and validated; identified errors are corrected promptly. \\
\hline 27 & Accounts receivable aging reports are prepared regularly and analyzed. \\
\hline 28 & Billing master files data is periodically reviewed by management for accuracy and on-going pertinence. \\
\hline 29 & $\begin{array}{l}\text { Recorded changes to billing master files data are compared to authorized source documents or confirmed with customers/attendees to } \\
\text { ensure that data was input accurately. }\end{array}$ \\
\hline 30 & Citizen complaints are handled independently from transaction processing. \\
\hline 31 & $\begin{array}{l}\text { Personnel who are responsible for invoicing and accounts receivable transaction processing have neither responsibility for master } \\
\text { billing files maintenance nor update access to the master billing files. }\end{array}$ \\
\hline 32 & Significant changes to master billing files are approved by management. \\
\hline 33 & Requests to change master billing files are logged; the log is reviewed to ensure that all requested changes are processed timely. \\
\hline 34 & $\begin{array}{l}\text { Requests to change master billing files are submitted on prenumbered forms; the numerical sequence of such forms is accounted for to } \\
\text { ensure that all requested changes are processed timely. }\end{array}$ \\
\hline 35 & Master billing files data is edited and validated; identified errors are corrected promptly. \\
\hline 36 & Collection procedures established by management for overdue accounts are performed as intended. \\
\hline 37 & General ledger balances are reconciled to the accounts receivable subsidiary ledger and differences are resolved in a timely manner. \\
\hline 38 & The AIS edits and validates financial documents on-line. \\
\hline 39 & The AIS restricts to authorized personnel the ability to create, change, or delete sales orders, contracts, and delivery schedules. \\
\hline 40 & The AIS reports of open sales documents are prepared and monitored to ensure timely shipment. \\
\hline 41 & The AIS restricts to authorized personnel the ability to modify the AIS sales pricing information. \\
\hline 42 & The AIS does not allow processing of sales orders that exceed customer credit limits. \\
\hline 43 & ment numbering are reviewed regularly. \\
\hline
\end{tabular}

\section{SUMMARY AND CONCLUSION}

This paper provides an internal control checklist for the general revenue cycle that can be used as a benchmark in determining whether sufficient internal controls are in place. In addition, this paper can be used in the classroom to demonstrate how public sector internal controls need to be designed. 


\section{AUTHOR INFORMATION}

Jeffrey L. Decker, Ph.D., CPA, is an Associate Professor at Indiana State University. He received his MBA from the University of Oregon and his Ph.D. from the University of Arizona. He has worked for Dana Corporation and NuTone Corporation. He can be reached at (812)229-4205, E-mail: Jeffrey.decker@indstate.edu or Scott College of Business, 200 North Seventh Street, Terre Haute, IN 47809.

\section{REFERENCES}

1. Brunsson, N. and K. Sahlin-Anderson, "Constructing Organizations: The Example of Public Sector Reform", Organization Studies, July 2000, Vol. 21, no. 4 pp. 721-746.

2. eHow Money, http://www.ehow.com/facts 6059986 public-sector-company .html.

3. Heinze, T.C., T. Kizirian, K. Sandoe, S. Lees. 2010. Internal Controls for the Revenue Cycle: A Checklist for the Consumer Products Industry. International Business and Economics Research Journal. August, 2010.

4. United States General Accounting Office (GAO), Standards for Internal Controls in the Federal Government, 1999, http://www.gao.gov/special.pubs/ai2131.pdf. 